\title{
Chemical composition and caloric content of egg and zoea of the hermit crab Eupagurus bernhardus
}

\author{
Thavamani J. Pandian and Karl-Heinz Schumann \\ Biologische Anstalt Helgoland, Meeresstation, Helgoland
}

\begin{abstract}
KURZFASSUNG: Chemische Zusammensetzung und Kaloriengehalt von Ei und Zoea des Einsiedlerkrebses Eupagurus bernbardus. Im Laufe der vollständigen Eientwicklung findet eine Zunahme von Wasser um 31,5\%, Asche um 5,7\%, Eiweiß um 8,8\% und Nicht-Eiweiß-Stickstoff um $0,2 \%$ statt. In der gleichen Zeit sinkt der Fettgehalt von $29,5 \%$ auf $14,8 \%$ und der Energiegehalt von 6292 auf $5282 \mathrm{cal} / \mathrm{g}$ organischer Substanz. Der Kumulativ-Nutzeffekt der Entwicklung von einem Ei zur Zoea-Larve beträgt 70,0\%, 55,3\%, 79,4\% bzw. 35,0\% bezogen auf Trockengewicht, Kaloriengehalt, Eiweiß bzw. Fett. Von den $0,0722 \mathrm{cal}$, die sich auf den Stoff wechsel der gesamten Entwicklung eines Eies beziehen, werden nur 28,4\% aus Eiweiß gewonnen; 66,6\% werden durch Oxydation von Fett beigetragen.
\end{abstract}

\section{INTRODUCTION}

Studies on the rate and efficiency of transformation of matter and energy in the developing eggs of crustaceans have received considerable attention in recent times (Urbani 1959, Kinne 1960, 1961, McLaren 1966, Taube \& Nauwerck 1967, PanDIAN 1967a). It has been shown that freshly hatched protozoea larvae of the shrimp Crangon crangon have utilized about $55 \%$ of the energy contained in the egg and that oxidation of fat was the main energy source for metabolism of the embryo (PANDIAN 1967a). This paper reports on the chemical composition and caloric content of the egg and zoea of the common hermit crab Eupagurus bernbardus.

\section{MATERIAL AND METHODS}

A collection of E. bernhardus LinNaeus (Paguridae, Anomura) was made near Helgoland in March 1967. All specimens were maintained under laboratory conditions. Immediately after copulation, the mother animals were transferred into suitable aquarium cylinders containing running sea-water maintained at about $12^{\circ} \mathrm{C}$. The fresh eggs were round, with an average diameter of about $750 \mu$, and deep violet in color. As the development proceeded, they became more or less oval and lighter in color; after a 35 to 40 day-incubation period (ScHumann unpublished) the zoea hatched. Eggs freshly attached to the pleopods and fresh hatched zoeae were collected for further studies. 
Details on the methods used have been published by Pandran (1967a). A definite number of eggs or zoeae was counted, washed free from adhering salt particles, weighed and dried at $80^{\circ} \mathrm{C}$ for a period of 4 hours. All weighings were made using a Sartorius balance with a sensitivity of $\pm 0.01 \mathrm{mg}$. Ash content was determined by incinerating the sample at $500^{\circ} \mathrm{C}$ for 5 hours. Protein content was estimated by nitrogen analysis following a standard micro-Kjeldhal procedure described by ROTH (1958). Caloric content was determined in a semi-micro bomb calorimeter (Parr Instrument Co., Model 1412). Three zoea samples were not completely combusted; the respective results were discarded.

Except for water content all percentages given hereafter are based on dry weight.

\section{RESULTS}

\section{Chemical composition and caloric content}

Water content: Due to technical difficulties water content of the samples could not be determined precisely. Results based on crude estimations suggest that water content increased from about $45.6 \%$ in the fresh egg to $77.1 \%$ in the zoea.

Dry weight: Total number of eggs and zoeae counted to determine the dry weights of a single egg and zoea are given in Table 1. A single egg weighed $26.7 \mu \mathrm{g}$, a zoea $18.7 \mu \mathrm{g}$; this indicates a net dry weight loss of $8.0 \mu \mathrm{g}$ during the entire development.

Table 1

Estimation of dry weight of a single egg of Eupagurus bernhardws at the beginning and end of the embryonic development

\begin{tabular}{|cccccc|}
\hline $\begin{array}{c}\text { Develop- } \\
\text { mental } \\
\text { stage }\end{array}$ & $\begin{array}{c}\text { Number of } \\
\text { mother } \\
\text { animals }\end{array}$ & $\begin{array}{c}\text { Total number } \\
\text { of eggs } \\
\text { counted }\end{array}$ & $\begin{array}{c}\text { Mean dry } \\
\text { weight of } \\
\text { one egg }(\mu \mathrm{gg})\end{array}$ & $\begin{array}{c}\text { Standard } \\
\text { deviation } \\
(\mu \mathrm{g})\end{array}$ & $\begin{array}{c}\text { Coefficient } \\
\text { of varia- } \\
\text { bility }(0 / 0)\end{array}$ \\
\hline $\begin{array}{l}\text { Fresh egg } \\
\text { Zoea larva }\end{array}$ & 7 & 7496 & 26.7 & \pm 2.3 & 8.6 \\
\hline
\end{tabular}

The samples collected in August 1967 gave very low values: $19.2 \mu \mathrm{g}$ for the egg and $12.5 \mu \mathrm{g}$ for the zoea (based on 1000 counts in each case). It is likely that late summer eggs were less heavy than early spring eggs. Some information from literature supports this assumption. CRISP (1959) reported that the eggs of Balanus balanoides of warm waters were smaller than those of cold waters (see also BARNES \& BARNES 1965). Maintaining warm water eurythermal barnacles at low temperatures, PATEL \& CRISP (1960) found that these produced larger eggs than at higher temperatures. PATel \& Crisp further reported that nauplii hatched from eggs developed in vitro outside the mantle cavity were larger at low temperature. These results suggest that temperature affects both size of the egg and embryo. 
Ash content, which was $3.8 \%$ in the fresh egg, increased to $9.5 \%$ in the zoea, amounting to about a $250 \%$ increase from its initial value (Table 2). Since salts are added to the dry weight of a zoea, it is obvious that the net dry weight (organic substance) loss by a developing egg is greater than $8.0 \mu \mathrm{g}$. Therefore, the dry weight of organic substance per egg and zoea was calculated, using the values given in Tables 1 and 2 ; it amounted to $25.7 \mu \mathrm{g}$ per egg and $16.9 \mu \mathrm{g}$ per zoea (see Table 4); thus the net loss of (dry) organic substance amounts to $8.8 \mu \mathrm{g}$ during the entire embryonic development.

All estimations were made on samples collected in early spring, except those on nitrogen which were conducted on late summer material. As pointed out above, egg and zoea had different sizes in early spring and late summer, respectively. It is,

Table 2

Chemical composition of the eggs of Eupagurus bernbardus at the beginning and end of the embryonic development. The numbers enclosed in brackets indicate the number of estimations made

\begin{tabular}{|ccccc|}
\hline $\begin{array}{c}\text { Developmental } \\
\text { stage }\end{array}$ & $\begin{array}{c}\text { Ash } \\
(\% / 0)\end{array}$ & $\begin{array}{c}\text { Protein } \\
(\% / 0)\end{array}$ & $\begin{array}{c}\text { Nonprotein } \\
\text { nitrogen }(\% / 0)\end{array}$ & $\begin{array}{c}\text { Fat } \\
(0 \%)\end{array}$ \\
\hline Fresh egg & $3.8(4)$ & $66.0(3)$ & $0.7(3)$ & 29.5 \\
Zoea larva & $9.5(6)$ & $74.8(3)$ & $0.9(3)$ & 14.8 \\
\hline
\end{tabular}

however, assumed that these differences did not affect the chemical composition of either. Protein content increased from $66.0 \%$ in the egg to $74.8 \%$ in the zoea. In the corresponding stages non-protein nitrogen increased from $0.7 \%$ to $0.9 \%$ (Table 2).

No direct estimation of fat content was made. Since the weights of organic substance and protein as well as non-protein nitrogen contents are known, and assuming that carbohydrates were in trace quantities, fat contents of egg and zoea were calcu-

Table 3

Caloric content of the eggs of Eupagurus bernhardus at the beginning and end of the embryonic development

\begin{tabular}{|lcccc|}
\hline $\begin{array}{c}\text { Developmental } \\
\text { stage }\end{array}$ & $\begin{array}{c}\text { Number of } \\
\text { estimates made }\end{array}$ & $\begin{array}{c}\text { Energy content } \\
\text { (cal/g dry wt.) }\end{array}$ & $\begin{array}{c}\text { Standard } \\
\text { deviation }\end{array}$ & $\begin{array}{c}\text { Energy content } \\
\text { (cal/g dry } \\
\text { organic } \\
\text { substance) }\end{array}$ \\
\hline Fresh egg & 5 & 6053 & \pm 388 & 6292 \\
Zoea larva & 5 & 4780 & \pm 496 & 5282 \\
\hline
\end{tabular}

lated. Fat content, which was $29.5 \%$ in the egg, decreased to $14.8 \%$ in the zoea (Table 2). Correspondingly, the caloric value also decreased from $6292 \mathrm{cal} / \mathrm{g}$ organic substance in the egg to $5282 \mathrm{cal} / \mathrm{g}$ organic substance in the zoea (Table 3 ). 


\section{Efficiency of yolk utilization}

From the values presented in Tables 1 to 3 , average chemical composition and caloric content of a single egg at the beginning and end of embryonic development are obtained (Table 4). The cumulative efficiency values (the ratio of: body formed to

Table 4

Chemical composition and caloric content of a single egg of Eupagurus bernbardus at the beginning and end of the embryonic development. All the values, except those of caloric contents, are given in micrograms

\begin{tabular}{|lcc|}
\hline Substance & Fresh egg & Zoea larva \\
\hline Dry weight & 26.70 & 18.70 \\
Ash content & 1.01 & 1.78 \\
Organic substance & 25.69 & 16.92 \\
Protein & 17.62 & 13.99 \\
Non-protein nitrogen & 0.19 & 0.17 \\
Fat & 7.88 & 2.76 \\
Caloric content (cal) & 0.1616 & 0.0894 \\
\hline
\end{tabular}

yolk used for metabolism + body formed, GRAY 1928) were 70.0\%, 65.9\%, 55.3\%, $79.4 \%$ or $35.0 \%$ for dry weight, organic substance, energy content, protein or fat. These values are in agreement with those reported for other crustaceans as Crangon crangon, Ligia oceanica, and Homarus gammarus (Pandian 1967a,b,c). The species specific differences observed in regard to the efficiency values indicate variations in efficiencies - possibly also rates - with which the different substances are utilized by the embryo. E. bernhardus expended $0.0722 \mathrm{cal}$ on metabolism during its development from egg to zoea. Of this amount only $28.4 \%(3.63 \mu \mathrm{g}$ protein $\times 5650 \mathrm{cal} / \mathrm{g}$ protein $=0.0205 \mathrm{cal}$, Table 4) was drawn by protein oxidation, while as much as $66.6 \%$ $(5.12 \mu \mathrm{g}$ fat $\times 9400 \mathrm{cal} / \mathrm{g}$ fat $=0.0481 \mathrm{cal})$ was supplied from fat. Thus, it may be concluded that oxidation of fat is the main energy source for the embryonic metabolism of E. bernhardus.

\section{DISCUSSION}

Water content $(31.5 \%)$ and inorganic salts $(5.7 \%$ or $0.77 \mu \mathrm{g} / \mathrm{egg})$ increase considerably during the embryonic development of the hermit crab Eupagurus bernhardus. Such increases seem to be a common feature in developing crustacean eggs, e. g., in Crangon crangon, Ligia oceanica, Homarus gammarus and Artemia salina (PANDIAN 1967a, b, c, d). While salts must have been absorbed from the surrounding seawater, it is not clear whether increase in water content is due to absorption of water and/or to the production of (metabolic) water by the oxidation of fat and protein.

Percentage values obtained for protein and fat contents of egg and zoea of E. bernbardus agree with those found in C. crangon (PANDIAN 1967a), except for some minor variations. The eggs of the former contain a higher protein content $(66.0 \%)$ and lower fat content $(29.5 \%)$ than those $(58.7 \%$ protein and $32.6 \%$ fat $)$ of the latter. 
These variations are further reflected in the caloric contents of the eggs. The values were $6443 \mathrm{cal} / \mathrm{g}$ and $6292 \mathrm{cal} / \mathrm{g}$ dry organic substance of the eggs of C. crangon and $E$. bernhardus, respectively. They do not appear to be related to the different feeding habits. Completely herbivorous crustaceans like Artemia salina (feeding mainly on green algae) and Ligia oceanica, said to feed exclusively on Fucus vesiculosus (Nicholls 1931), produce eggs with quite different caloric properties; the caloric values per gram dry organic substance amount to 5637 and 6000 in the eggs of $A$. salina and L. oceani$c a$, respectively. Thus, these variations appear to have some other ecophysiological significance, which will be discussed elsewhere.

The main energy source for the embryonic metabolism of $E$. bernbardus was fat oxidation $(66.6 \%)$; only $28.4 \%$ of the total energy was derived from protein. Eggs of Crangon crangon use only $20.8 \%$ protein (PANDIAN 1967a). Fat serves as main energy source for the developing eggs of Ligia oceanica and Homarus gammarus (PANDIAN 1967b, c). In fact, it appears that marine molluscs also use fat as main energy source during their embryonic development. Thus, as much as $61.5 \%$ of the total energy used was drawn from fat oxidation in developing eggs of the squid Loligo vulgaris (Stolfr 1933). The slipper limpet Crepidula fornicata, has also been found to use larger quantities $(66 \%)$ of fat (Pandian 1967e). According to Ockelmann (personal communication), in many marine lamellibranchs, the dense fat globules of fresh eggs gradually disappeared as development proceeded. This suggests again utilization of considerable quantities of fat during development. Upon oxidation, fat releases large quantities of water $(1 \mathrm{~g}$ fat releases $1.07 \mathrm{~g}$ water, $1 \mathrm{~g}$ protein only $0.41 \mathrm{~g}$ water; BALDWIN 1964, p. 52) and unlike protein, fat oxidation does not result in ammonia production, the removal of which costs considerable quantities of water. These two properties of fat, namely production and conservation of water, obviously represent advantages for eggs of marine organisms to which water is not as readily available as is the case in freshwater species. Such a generalization may, however, be premature; it would differ from the concept of Needham (1950, pp. 39-41). Depending on the nature of the substance used as energy source during the development, NEEDHAM distinguished between terrestrial animals with fat as main energy source, and aquatic animals, which derive their energy primarily by oxidizing protein. Further work in this field is urgently needed.

\section{SUMMARY}

1. Chemical composition and caloric content of egg and zoea of the hermit crab Eupagurus bernhardus have been determined and the cumulative efficiencies of yolk utilization calculated.

2. The cumulative efficiencies of yolk utilization for different constituents were $70.0 \%, 55.3 \%, 79.4 \%$ or $35.0 \%$ for dry weight, caloric content, protein or fat.

3. Since the efficiencies with which the different constituents of yolk utilized vary, the chemical composition of the developing eggs undergoes considerable changes. While fat and caloric content showed remarkable decreases, water, ash and protein contents of the eggs increased. 
4. Of $0.0722 \mathrm{cal}$ expended on metabolic processes of the embryo, only $28.4 \%$ was drawn from the oxidation of protein, while fat contributed as much as $66.6 \%$.

5. Considerable quantities of inorganic salts $(0.77 \mu \mathrm{g} / \mathrm{egg})$ are absorbed from the seawater by the developing egg.

Acknowledgements: We are very grateful to Prof. O. Krnne, Leading Director of the Biologische Anstalt Helgoland, for offering criticism and helpful suggestions. This work was financially supported by the grant given to Prof. O. Kinne (Ki 41/14) by the Deutsche Forschungsgemeinschaft and the Deutsche Akademische Austauschdienst (T.J.P.).

\section{LITERATURE CITED}

Baldwin, E., 1964. An introduction to comparative biochemistry. 4th ed. Univ. Press, Cambridge, $179 \mathrm{pp}$.

Barnes, H. \& BARnes, M., 1965. Egg size, nauplius size and their variation with local, geographical and specific factors in some common cirripedes. J. Anim. Ecol. 34, 391-402.

CRISP, D. J. P., 1959. Factors affecting the time of breeding of Balanus balanoides. Oikos 10, 275-289.

GraY, J., 1928. The growth of fish. 2. The growth-rate of the embryo of Salmo fario. J. exp. Biol. 6, 110-124.

KINNE, O., 1960. Gammarus salinus - Einige Daten über den Umwelteinfluß auf Wachstum, Häutungsfolge, Herzfrequenz und Eientwicklungsdauer. Crustaceana 1, 208-217.

- 1961. Growth, molting frequence, heart beat, number of eggs and incubation time in Gammartis zaddachi exposed to different environment. Crustaceana 2, 26-36.

McLAREN, I. A., 1966. Predicting development rate in copepod eggs. Biol. Bull. mar. biol. Lab., Woods Hole 131, 457-469.

NeEdham, J., 1950. Biochemistry and morphogensis. Univ. Press, Cambridge, 785 pp.

Nicholls, A. G., 1931. Studies on Ligia oceanica. 1. Habitat and effect of change of environment on respiration. Observations on molting and breeding. J. mar. biol. Ass. U. K. 17, 655-673.

Pandian, T. J., 1967a. Changes in the chemical composition and caloric content of developing eggs of the shrimp Crangon crangon. Helgoländer wiss. Meeyesunters. 16, 216-224.

- $1967 \mathrm{~b}$. Changes in the chemical composition and caloric content of developing eggs of Ligia oceanica. (Unpubl.)

- 1967c. Chemical composition and caloric content of developing eggs of the lobster Homarus gammarus. (Unpubl.)

- $1967 \mathrm{~d}$. Changes in the chemical composition and caloric content of developing eggs of the brine shrimp Artemia salina. (Unpubl.)

- 1967e. Changes in the chemical composition and caloric content of developing eggs of the slipper limpet Crepidula fornicata. (Unpubl.)

PATEL, B. \& CRISP, D. J., 1960. Influence of temperature in the breeding and molting activities of some warm water species of operculate barnacles. J. mar. biol. Ass. U. K. 39, 667-680.

PREgL, F. \& Roth, H., 1958. Quantitative organische Mikroanalyse. 7. Aufl. von H. Roth. Springer, Wien, $361 \mathrm{pp}$.

Stolfi, G., 1933. L'accrescimento embrionale del Loligo vulgaris. Atti Accad. naz. Lincei Rc. (Cl. Sci. fis. mat. nat.) $\mathbf{1 8}(6), 516 \mathrm{ff}$.

TAUBe, I. \& Nauwerck, A., 1967. Zur Populationsdynamik von Cyclops scutifer SARs. 1. Die Temperaturabhängigkeit der Embryonalentwicklung von Cyclops scutifer SARs im Vergleich zu Mesocyclops leuckarti (Cunus). Rep. Inst. Freshwat. Res. Drottningholm 47, 76-86.

URBANI, E., 1959. Protidi, glucidi e lipidi nello sviluppo di Artemia salina Leach. Acta Embryol. Morph. exp. 2, 171-194. 